Rapid Communication

\title{
Middle Paleolithic occupation on a Marine Isotope Stage 5 lakeshore in the Nefud Desert, Saudi Arabia
}

\author{
Michael D. Petraglia ${ }^{\mathrm{a}, *}$, Abdullah M. Alsharekh ${ }^{\mathrm{b}}$, Rémy Crassard ${ }^{\mathrm{c}}$, Nick A. Drake ${ }^{\mathrm{d}}$, \\ Huw Groucutt ${ }^{\mathrm{a}}$, Adrian G. Parker ${ }^{\mathrm{e}}$, Richard G. Roberts ${ }^{\mathrm{f}}$ \\ a School of Archaeology, Research Laboratory for Archaeology and the History of Art, University of Oxford, Oxford OX12HU, UK \\ ${ }^{\mathrm{b}}$ Department of Archaeology, College of Tourism \& Archaeology, King Saud University, Riyadh, Saudi Arabia \\ ${ }^{c}$ CNRS, UMR5133, Maison de l'Orient et de la Méditerranée, Lyon, France \\ d Department of Geography, King's College, London, UK \\ e Department of Anthropology and Geography, Oxford Brookes University, Oxford, UK \\ ${ }^{\mathrm{f}}$ Centre for Archaeological Science, School of Earth E' Environmental Sciences, University of Wollongong, Wollongong, Australia
}

\section{A R T I C L E I N F O}

\section{Article history:}

Received 18 December 2010

Received in revised form

29 March 2011

Accepted 8 April 2011

Available online 12 May 2011

\section{Keywords:}

Paleolithic

Paleolake

Arabia

Optically stimulated luminescence

\begin{abstract}
A B S T R A C T
Major hydrological variations associated with glacial and interglacial climates in North Africa and the Levant have been related to Middle Paleolithic occupations and dispersals, but suitable archaeological sites to explore such relationships are rare on the Arabian Peninsula. Here we report the discovery of Middle Paleolithic assemblages in the Nefud Desert of northern Arabia associated with stratified deposits dated to 75,000 years ago. The site is located in close proximity to a substantial relict lake and indicates that Middle Paleolithic hominins penetrated deeply into the Arabian Peninsula to inhabit landscapes vegetated by grasses and some trees. Our discovery supports the hypothesis of range expansion by Middle Paleolithic populations into Arabia during the final humid phase of Marine Isotope Stage 5, when environmental conditions were still favorable.
\end{abstract}

(c) 2011 Elsevier Ltd. All rights reserved.

\section{Introduction}

Demographic expansions, contractions and extinctions of human populations have been related to climatic oscillations in the Late Pleistocene (Foley and Lahr, 1998). The expansion of Middle Stone Age populations into parts of East Africa and the Sahara is considered a consequence of environmental amelioration during the Last Interglacial, Marine Isotope Stage (MIS) 5, with dispersals concentrated along river valleys and lakeshores to find attractive habitats (Basell, 2008; Osborne et al., 2008; Drake et al., 2011). In Arabia, the activation of major river systems and lakes (Parker, 2009) is likewise hypothesized to be linked to hominin expansions (Rose and Petraglia, 2009; Petraglia et al., 2010), although no convincing association between Pleistocene habitats and archaeological materials with reliable age control has been reported for interior Arabia. The site of Jebel Faya in southeastern Arabia,

\footnotetext{
* Corresponding author.

E-mail addresses: michael.petraglia@rlaha.ox.ac.uk (M.D. Petraglia), asharekh@ hotmail.com (A.M. Alsharekh), remy.crassard@mom.fr (R. Crassard), nick.drake@ kcl.ac.uk (N.A. Drake), huw.groucutt@rlaha.ox.ac.uk (H. Groucutt), agparker@ brookes.ac.uk (A.G. Parker), rgrob@uow.edu.au (R.G. Roberts).
}

containing stratified Paleolithic assemblages, has recently been dated to between 125 and $40 \mathrm{ka}$ (Armitage et al., 2011). At present, the paucity of archaeological and hominin fossil material in Arabia a key region connecting Africa and Eurasia - leaves a significant gap in dispersal narratives, particularly, but not necessarily exclusively, those concerning expansions out of Africa.

Habitable environments for human occupation were certainly present in Arabia during the Late Pleistocene. Lacustrine and riverine deposits have been identified in the Empty Quarter of southern Arabia (McClure, 1976), in the Nefud Desert of northern Arabia (Schultz and Whitney, 1986), and at the Saudi-Jordanian border, where a vast lake existed in MIS 5 (Petit-Maire et al., 2010). The activation of these wet systems relates to increased moisture from Mediterranean weather systems in the north (Bar-Matthews et al., 2003) and from the Indian Ocean monsoon in the south (Fleitmann and Matter, 2009). In the Nefud Desert and surrounding drylands, the presence of Middle Paleolithic hominins is demonstrated by the occurrence of numerous surface archaeological localities (Petraglia and Alsharekh, 2003). Here we report Middle Paleolithic lithic assemblages associated with stratified deposits in close proximity to a major lake basin in the Nefud Desert (Fig. 1) and place this early occupation of the Arabian interior in environmental context. 


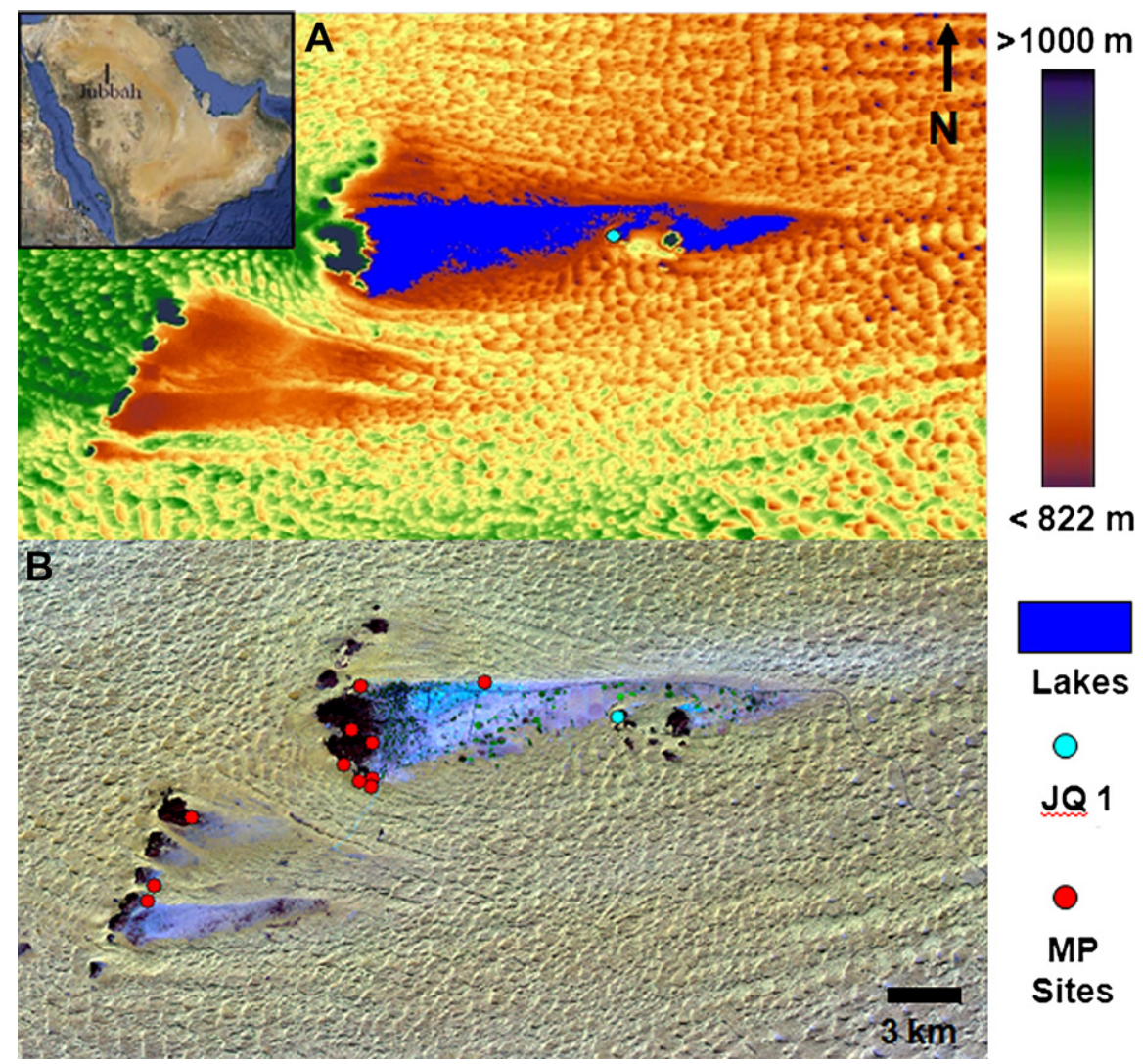

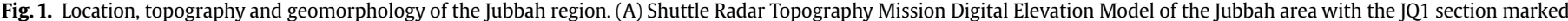

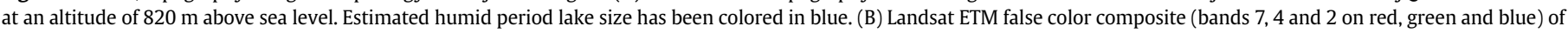

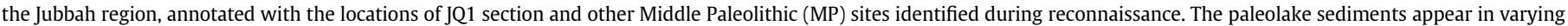
shades of blue to white, the rock outcrops are black, and the sand dunes light yellow. Note the distribution of MP sites around the margin of the paleolake.

\section{Study site}

The site of Jebel Qattar 1 (JQ1) is located close to the edge of a paleolake near Jubbah $\left(28^{\circ} 00^{\prime} 53.5 \mathrm{~N}, 41^{\circ} 03^{\prime} 35.6 \mathrm{E}, 820 \mathrm{~m}\right.$ above sea level). The paleolake measures at least $20 \mathrm{~km}$ (east-west) and $4 \mathrm{~km}$ (north-south) (Fig. 1); the full extent of the lake is concealed beneath eolian sand on its northern, southern and eastern boundaries. The exposed part of the paleolake lies downwind of large sandstone outcrops, particularly Jebel Umm Sanman to the west, which has diverted the westerly flow of sand around the outcrop, leaving a sand-free depression in its lee that filled with water during past humid periods. 'Mousterian' lithic assemblages were first reported from a factory/quarry site near the summit of Jebel Umm Sanman and sites around the lake (Garrard et al., 1981). The artifacts were found on the ground surface, as is commonly the case for other reported Paleolithic occurrences in Arabia (Petraglia and Alsharekh, 2003). The adjacent lake is filled with stratified sediments extending to a depth of $\sim 26 \mathrm{~m}$, with most of this sequence underlying a radiocarbon age of 25,630 $\pm 430 \mathrm{BP}$ (Q-3117) (Garrard et al., 1981). During our reconnaissance of the area in March 2010, we recorded JQ1 and additional Middle Paleolithic occurrences along the edges of the paleolakes and jebels around Jubbah (Fig. 1), indicating a wealth of archaeological sites spread over a wide area. We also found stratified sequences that extend more than $30 \mathrm{~m}$ in depth, confirming earlier observations of stratified Holocene and Pleistocene deposits.

JQ1 is situated just south of Jebel Qattar, which reaches a maximum height of $905 \mathrm{~m}$ above sea level. The site consists of exposed sedimentary deposits, which are overlain by a $30 \mathrm{~m}$-high sand dune. Excavation of a $1 \mathrm{~m}$-wide trench demonstrated that JQ1 preserves more than $3 \mathrm{~m}$ depth of sediments, including calcretes and weakly developed/incipient paleosols within sandy deposits (Fig. 2). We used optically stimulated luminescence (OSL) dating (Lian and Roberts, 2006; Jacobs and Roberts, 2007) to obtain burial ages for sand-sized grains of quartz. Two OSL ages were obtained for deposits below and above the main calcrete layer $(211 \pm 16$ and $95 \pm 7 \mathrm{ka}$, respectively), and for grains extracted from the topmost pedocalcrete $(75 \pm 5 \mathrm{ka})$; see Supplementary information for details. The OSL ages are in correct stratigraphic order and indicate that the sediments in which the incipient paleosols/calcretes developed were deposited in MIS 7, 5c and 5a. We attribute the phase of main calcrete formation to MIS 5e. The latter sediments are characterized by comparatively high organic content (determined by loss-on-ignition) and magnetic susceptibility values (Fig. S2). At the base of this calcrete, phytolith and carbon isotope analyses reveal a $C_{3}$ Pooid-dominated grassland with some $C_{4}$ Panicoid and Chloridoid elements. Phytoliths are mostly absent higher in this calcrete. The MIS $5 \mathrm{c}$ paleosol consists of mediumgrained sand with calcareous rhizolith casts and phytoliths that indicate $C_{3}$ Pooid-dominated grassland with some tree cover and $C_{4}$ Panicoid, but little $\mathrm{C}_{4}$ Chloridoid grass cover; this interpretation is corroborated by carbon isotope values of $-23 \%$. The uppermost pedocalcrete is dated to MIS $5 a$ and shows a return to higher magnetic susceptibility values, with phytoliths that indicate a landscape dominated by a mix of $C_{3}$ Pooid and $C_{4}$ Panicoid and Chloridoid grassland types, with some trees. A shift to drier conditions during MIS $5 \mathrm{a}$ is indicated by a slight increase in $C_{4}$ Chloridoid grasses coupled with a $2 \%$ shift in carbon isotope values, but the vegetation is never dominated by $\mathrm{C}_{4}$ flora. 
MIS

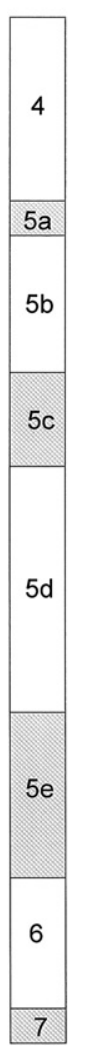

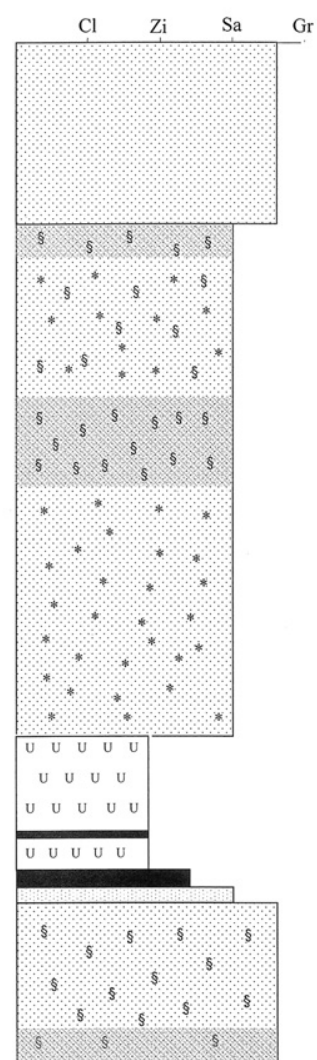

Sand

Calcrete

Sand

Paleosol

Sand

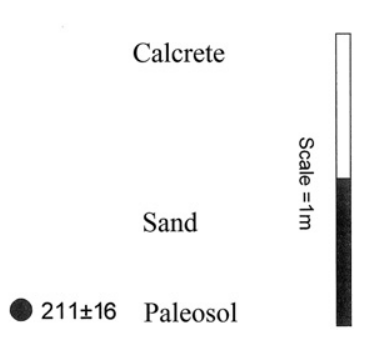

Fig. 2. Jebel Qattar (JQ1) stratigraphic section. The stratigraphic column shows the locations of the incipient paleosols, calcretes and the OSL ages. The bar to the left indicates that the OSL ages correspond to MIS 7 ( $211 \pm 16 \mathrm{ka})$, MIS 5c (95 $\pm 7 \mathrm{ka})$, and MIS 5a $(75 \pm 5 \mathrm{ka})$. The archaeological assemblage is associated with the upper pedocalcrete (MIS 5a). The inter-stratifed sands between the paleosols are interpreted as MIS 6 , MIS $5 \mathrm{~d}$ and MIS $5 \mathrm{~b}$ deposits, and the capping dune sands as MIS 4.
In arid/semi-arid regions such as the Jubbah basin, it is likely that increased wetness during interglacial stages, coupled with increased vegetation cover and landscape stability, was crucial in promoting calcrete formation at JQ1. Calcrete formation during moister phases of the Quaternary has been reported for other arid/ semi-arid regions, including Spain (Candy and Black, 2009), southwest Australia (Semeniuk and Searle, 1985) and the Thar Desert of India (Andrews et al., 1998). The MIS 5a pedocalcrete is overlain by massive sands, representing a major change in depositional regime, which we interpret as evidence for drying of the landscape near the start of the last glacial period, in MIS 4. This climatic reconstruction is consistent with other dated records for the region (e.g., Vaks et al., 2007; Preusser, 2009; Petit-Maire et al., 2010; Waldmann et al., 2010).

The JQ1 stone-tool assemblage was collected from an area measuring $200 \times 50 \mathrm{~m}^{2}$. The artifacts were situated at the interface between the upper pedocalcrete, dated to $75 \pm 5 \mathrm{ka}$, and the overlying dune sands (Fig. 2). Carbon isotope and phytolith analyses indicate that the MIS 5a landscape was dominated by a mix of $\mathrm{C}_{3}$ and $\mathrm{C}_{4}$ grassland vegetation with some trees (Fig. S2). An increase in $\mathrm{C}_{4}$ grasses and carbon isotope values from the bottom to the top of this pedocalcrete indicates a shift to drier conditions toward the onset of MIS 4, and the recovery of ostrich eggshell fragments associated with this calcrete also testifies to the open nature of the habitat.

\section{Lithic technology}

We collected 160 chipped stone artifacts, recording Global Positioning Satellite points on each piece. The artifacts consist of 15 cores, 123 pieces of debitage (102 flakes, 13 blades, 8 chunks), and 22 tools. Core types include discoidal, centripetal Levallois (one with a large preferential removal) and multiplatform. Frequent faceting of platforms is evident. Flakes and blades were struck from prepared cores by direct hard-hammer percussion. The 22 tools
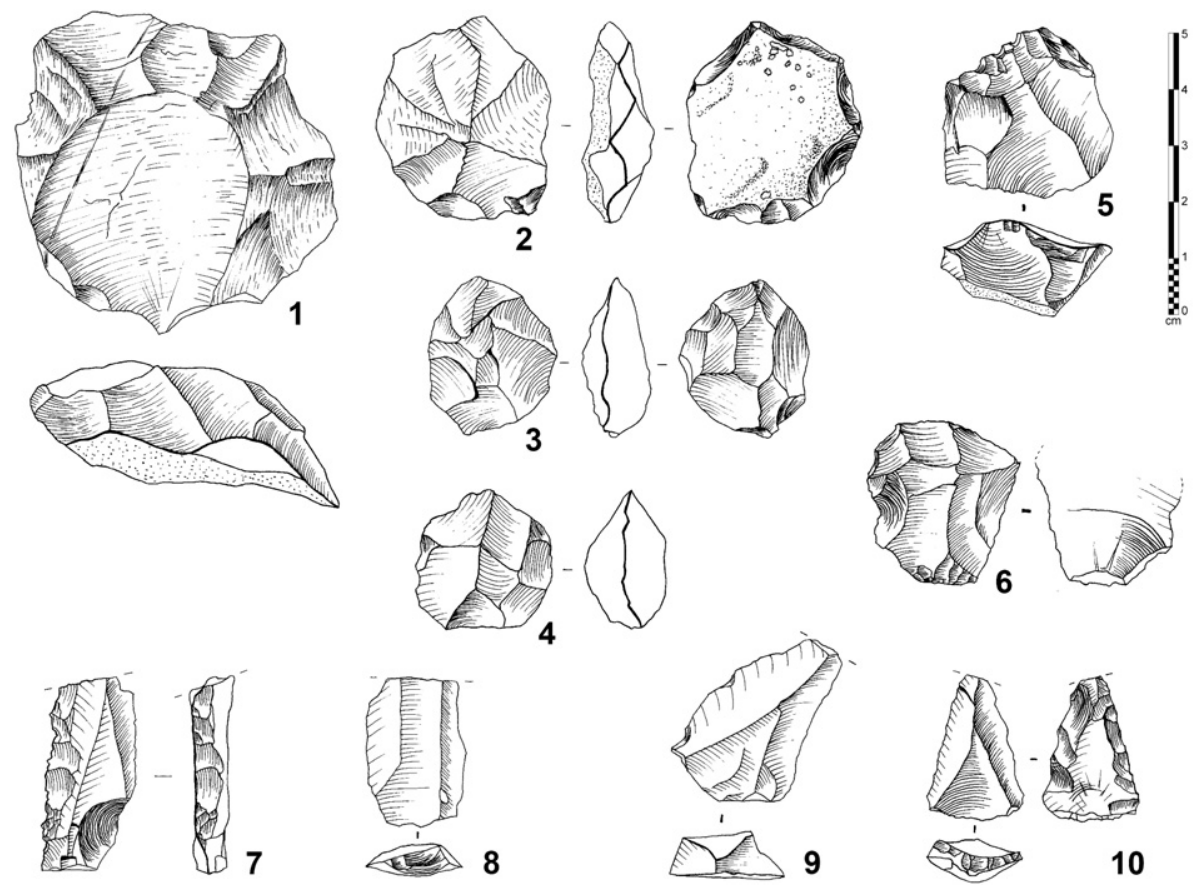

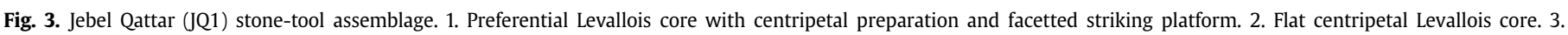

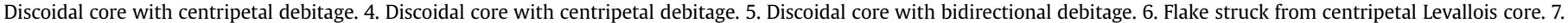

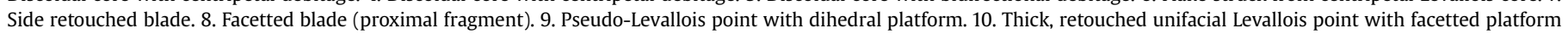
and ventral stepped retouch along two lateral edges. 
include denticulates and notches, flakes and blades that were informally retouched along their end- and side-margins, a small early-stage biface (62 $\mathrm{mm}$ in length), a pseudo-Levallois point (Fig. 3, no. 9) and a unifacial point (Fig. 3, no. 10). Raw materials include ferruginous quartzite (67\%), sandstone (11\%), flint $(9 \%)$, quartz (7\%), rhyolite (4\%) and other materials (2\%). The ferruginous quartzite outcrops as seams along the base of Jebel Qattar, so distance of transport to JQ1 is no greater than $100 \mathrm{~m}$. Technologically similar artifacts are found distributed over $>500$ linear meters along the base of the jebel, indicative of procurement behavior and activities. The artifact scatters are associated with tufa deposits that preserve abundant rhizoliths, further indicating that freshwater sources were available during humid phases. The recovery of small numbers of rhyolite artifacts implies long-distance transport, since no volcanic exposures have yet been identified near Jubbah. Based on the technology and antiquity of the stone tools discovered at JQ1, we can comfortably assign the assemblage to the Arabian Middle Paleolithic.

\section{Discussion and conclusions}

We have presented archaeological evidence, from a stratified context, indicating that Middle Paleolithic hominins were living along the shores of a lake in the Nefud Desert during the final humid phase of MIS 5. The JQ1 artifact assemblage indicates that Middle Paleolithic populations expanded their range into the Arabian Peninsula during a stage, when there were desirable habitats and sources of freshwater (Preusser, 2009). The presence of Middle Paleolithic technology in northern Arabia in MIS 5a is consistent with the identification of contemporaneous Middle Stone Age assemblages in East Africa (Basell, 2008), Mousterian technology in the Levant (Shea, 2008; Frumkin et al., 2011), and the MIS 5 assemblage from Jebel Faya, UAE (Armitage et al., 2011).

We have described the first reported Middle Paleolithic site associated with stratified deposits from interior Arabia. These discoveries are pertinent to ongoing debates about the timing, nature and routes of Late Pleistocene hominin dispersals, by enhancing our understanding of the spatial and temporal distributions of hominin occupations and showing that hominins were present in northern Arabia during pluvial periods. Further fieldwork and detailed technological comparisons of lithic assemblages will help contextualize discoveries from the Nefud Desert in terms of similarities and differences with Late Pleistocene assemblages from southern Arabia, East Africa and the Nile/Levant. A "green" Nefud could have been reached by dispersing populations from East Africa via southern Arabia, or by a northern route from the Sinai Peninsula/Levant (Petraglia, 2011). At present, no firm conclusions can be drawn about dispersal routes, but given the severe fluctuations in paleoclimate indicated by the JQ1 sedimentary record, we consider it unlikely that hominins occupied the Jubbah basin on a continuous, long-term basis.

Given the current absence of pre-Holocene hominin fossils in Arabia, and the fact that Levantine Mousterian assemblages are associated with both early modern humans and Neanderthals, caution is warranted in attributing a maker to the JQ1 and other Arabian Middle Paleolithic assemblages. The recovery of Middle Paleolithic artifacts at $75 \mathrm{ka}$, however, is consistent with the hypothesis that human populations utilized the southern route in MIS 5 (Petraglia et al., 2007). If modern humans were responsible for the early Arabian toolkit, then our findings contradict the argument that the dispersal of Homo sapiens out of Africa was accompanied by a microblade technology $60 \mathrm{ka}$ ago (Mellars, 2006). Furthermore, the presence of JQ1 in the interior of northern Arabia, $500 \mathrm{~km}$ from the nearest coast, indicates that an exclusive coastal corridor for hominin expansion out of Africa
(Stringer, 2000; Macaulay et al., 2005; Armitage et al., 2011) can no longer be assumed. Further archaeological and paleoanthropological research across the Arabian Peninsula will address these questions. The discoveries described here demonstrate the huge research potential of the region and the intimate relationships between climate change and hominin population history.

\section{Acknowledgments}

We thank HRH Prince Sultan bin Salman, President of the General Commission for Tourism and Antiquities, and Ali Ghabban, Vice President for Antiquities and Museums, for permission to carry out this study. We also thank Hussain Abu AlHassan, Abdulaziz Al-Omari, Habeeb Turki and the people of Jubbah for their support and assistance with the field investigations, the Arts and Humanities Research Council for a doctoral studentship to H.G., Yasaman Jafari for laboratory assistance, Allan Chivas for field assistance and advice on calcretes, the Australian Research Council (DP0880675) and the Saudi Commission for Tourism and Antiquities for funding, and two anonymous reviewers and Nicole Boivin for comments on a draft of this article.

\section{Appendix. Supplementary material}

Supplementary data related to this article can be found online at doi:10.1016/j.quascirev.2011.04.006.

\section{References}

Andrews, J.E., Singhvi, A.K., Kailath, A.J., Kuhn, R., Dennis, P.F., Tandon, S.K., Dhir, R.P. 1998. Do stable isotope data from calcrete record Late Pleistocene monsoonal climate variation in the Thar Desert of India? Quaternary Research 50, 240-251.

Armitage, S.J., Jasim, S.A., Marks, A.E., Parker, A.G., Usik, V.I., Uerpmann, H.-P., 2011 The southern route "out of Africa": evidence for an early expansion of modern humans into Arabia. Science 331, 453-456.

Bar-Matthews, M., Ayalon, A., Gilmour, M., Matthews, A., Hawkesworth, C.J., 2003 Sea-land oxygen isotopic relationships from planktonic foraminifera and speleothems in the Eastern Mediterranean region and their implications for paleorainfall during interglacial intervals. Geochimica et Cosmochimica Acta 67, 3181-3199.

Basell, L., 2008. Middle Stone Age (MSA) site distributions in eastern Africa and their relationship to Quaternary environmental change, refugia and the evolution of Homo sapiens. Quaternary Science Reviews 27, 2484-2498.

Candy, I., Black, S., 2009. The timing of Quaternary calcrete development in semiarid southeast Spain: investigating the role of climate on calcrete genesis. Sedimentary Geology 218, 6-15.

Drake, N.A., Blench, R.M., Armitage, S.J., Bristow, C.S., White, K.H., 2011. Ancient watercourses and biogeography of the Sahara explain the peopling of the desert. Proceedings of the National Academy of Sciences of America 108 (2) 458-462.

Fleitmann, D., Matter, A., 2009. The speleothem record of climate variability in southern Arabia. Comptes Rendus Geoscience 341, 633-642.

Foley, M.M., Lahr, R.A., 1998. Towards a theory of modern human origins: geography, demography, and diversity in recent human evolution. Yearbook of Physical Anthropology 41, 137-176.

Frumkin, A., Bar-Yosef, O., Schwarcz, H.P., 2011. Possible paleohydrologic and paleoclimatic effects on hominin migration and occupation of the Levantine Middle Paleolithic. Journal of Human Evolution 60, 437-451.

Garrard, A.N., Harvey, C.P.D., Switsur, V.R., 1981. Environment and settlement during the Upper Pleistocene and Holocene at Jubba in the Great Nefud, Northern Arabia. Atlal 5, 137-148.

Jacobs, Z., Roberts, R.G., 2007. Advances in optically stimulated luminescence dating of individual grains of quartz from archeological deposits. Evolutionary Anthropology 16, 210-223.

Lian, O.B., Roberts, R.G., 2006. Dating the Quaternary: progress in luminescence dating of sediments. Quaternary Science Reviews 25, 2449-2468.

Macaulay, V., Hill, C., Achilli, A., Rengo, C., Clarke, D., Meehan, W., Blackburn, J. Semino, O., Scozzari, R., Cruciani, F., Taha, A., Shaari, N.K., Raja, J.M., Ismail, P., Zainuddin, Z., Goodwin, W., Bulbeck, D., Bandelt, H.-J., Oppenheimer, S. Torroni, A., Richards, M., 2005. Single, rapid coastal settlement of Asia revealed by analysis of complete mitochondrial genomes. Science 308, 1034-1036.

McClure, H.A., 1976. Radiocarbon chronology of late Quaternary lakes in the Arabian desert. Nature 263, 755-756.

Mellars, P., 2006. Why did modern human populations disperse from Africa ca 60,000 years ago? A new model. Proceedings of the National Academy of Sciences of the USA 103, 9381-9386. 
Osborne, A.H., Vance, D., Rohling, E.J., Barton, N., Rogerson, M., Fello, N., 2008 A humid corridor across the Sahara for the migration of early modern humans out of Africa 120,000 years ago. Proceedings of the National Academy of Sciences of the USA 105, 16444-16447.

Parker, A.G., 2009. Developing a framework for hominin dispersal over the last 350 ka. In: Petraglia, M.D., Rose, J.I. (Eds.), The Evolution of Human Populations in Arabia: Paleoenvironments, Prehistory and Genetics. Springer Press, Netherlands, pp. 39-49.

Petit-Maire, N., Carbonel, P., Reyss, J.L., Sanlaville, P., Abed, A., Bourrouillh, R Fontugne, M., Yasin, S., 2010. A vast Eemian palaeolake in southern Jordan $\left(29^{\circ} \mathrm{N}\right)$. Global and Planetary Change $72,368-373$.

Petraglia, M.D., 2011. Trailblazers across Arabia. Nature 470, 50-51.

Petraglia, M.D., Alsharekh, A., 2003. The Middle Palaeolithic of Arabia: implication for modern human origins, behaviour and dispersals. Antiquity 77, 671-684.

Petraglia, M.D., Haslam, M., Fuller, D.Q., Boivin, N., Clarkson, C., 2010. Out of Africa: new hypotheses and evidence for the dispersal of Homo sapiens along the Indian Ocean rim. Annals of Human Biology 37, 288-311.

Petraglia, M.D., Korisettar, R., Boivin, N., Clarkson, C., Ditchfield, P., Jones, S. Koshy, J., Lahr, M.M., Oppenheimer, C., Pyle, D., Roberts, R., Schwenninger, J.-L, Arnold, L., White, K., 2007. Middle Paleolithic assemblages from the Indian subcontinent before and after the Toba super-eruption. Science 317 (5834), $114-116$
Preusser, F., 2009. Chronology of the impact of Quaternary climate change on continental environments in the Arabian Peninsula. Comptes Rendus Geoscience 341, 621-632.

Rose, J.I., Petraglia, M.D., 2009. Tracking the origin and evolution of human populations in Arabia. In: Petraglia, M.D., Rose, J.I. (Eds.), The Evolution of Human Populations in Arabia: Paleoenvironments, Prehistory and Genetics. Springer Press, Netherlands, pp. 1-12.

Schultz, E., Whitney, J.W., 1986. Upper Pleistocene and Holocene lakes in the An Nafud, Saudi Arabia. Hydrobiologia 143, 175-190.

Semeniuk, V., Searle, D.J., 1985. Distribution of calcrete in Holocene coastal sands in relationship to climate, southwestern Australia. Journal of Sedimentary Research 55, 86-95.

Shea, J.J., 2008. Transitions or turnovers? Climatically-forced extinctions of Homo sapiens and Neanderthals in the east Mediterranean Levant. Quaternary Science Reviews 27, 2253-2270.

Stringer, C., 2000. Coasting out of Africa. Nature 405, 24-27.

Vaks, A., Bar-Matthews, M., Ayalon, A., Matthews, A., Halicz, L., Frumkin, A., 2007. Desert speleothems reveal climatic window for African exodus of early modern humans. Geology 35, 831-834.

Waldmann, N., Torfstein, A., Stein, M., 2010. Northward intrusions of low- and midlatitude storms across the Saharo-Arabian belt during past interglacials. Geology 38, 567-570. 